\title{
Preparation and characterisation of polyaluminium silicate chloride coagulant
}

\section{Y.H. Song , Z.K. Luan \& H.X. Tang}

To cite this article: Y.H. Song , Z.K. Luan \& H.X. Tang (2003) Preparation and characterisation of polyaluminium silicate chloride coagulant, Environmental Technology, 24:3, 319-327

To link to this article: http://dx.doi.org/10.1080/09593330309385564

曲 Published online: 17 Dec 2008.

Submit your article to this journal ¿

Џ Article views: 63

Q View related articles $\square$

Citing articles: 5 View citing articles $\square$ 


\title{
PREPARATION AND CHARACTERISATION OF POLYALUMINIUM SILICATE CHLORIDE COAGULANT
}

\author{
${ }^{1 *}$ TTC-WGT, Forschungszentrum Karlsruhe GmbH, P.O. Box 3640, 76021 Karlsruhe, Germany \\ ${ }^{1}$ State Key Laboratory of Environmental Aquatic Chemistry, Research Center for Eco-Environmental Sciences, Chinese Academy \\ of Sciences, 100085 Beijing, China \\ ${ }^{2}$ Department of Chemical Engineering, Shandong University of Science and Technology, 250031 Jinan, China
}

(Received 11 July 2001; Accepted 22 July 2002)

\begin{abstract}
To improve the coagulation efficiency for water treatment purposes, a composite aluminium-silicon coagulant, the polyaluminium silicate chloride was prepared and characterised. The preparation process included the preparation of polyaluminium chloride and polysilicic acid followed by the compounding of the two solutions. The prepared polyaluminium silicate chloride coagulant solution had an aluminium concentration of 0.10 mole per litre, hydroxyl to aluminium molar ratios between 0.5 and 2.0 , and silicon to aluminium molar ratios between 0.025 and 0.075 . Aluminium-27 nuclear magnetic resonance spectroscopy, photon correlation spectroscopy, streaming current measurement, jar tests and pilot-scale coagulation tests were employed to study the aluminium speciation, particle size distribution, electrokinetic and coagulation properties of this composite coagulant. In comparison with polyaluminium chloride, polyaluminium silicate chloride contains less polynuclear aluminium $\left[\mathrm{AlO}_{4} \mathrm{Al}_{12}(\mathrm{OH})_{24}\left(\mathrm{H}_{2} \mathrm{O}\right)_{12}\right]^{2+}$ and shows smaller charge neutralisation capacity. However, its particle size shows a significant increase, which enhances the coagulation efficiency. The results show that polyaluminium silicate chloride is an efficient composite coagulant for water treatment.
\end{abstract}

Keywords: Coagulant, polyaluminium silicate chloride, aluminium speciation, water treatment.

\section{INTRODUCTION}

In water and wastewater treatments, cost effective coagulants are continuously developed to enhance treatment capacity. Inorganic composite polymeric coagulants have been developed rapidly during the 1990s, and composite aluminium-silicon coagulants represent an important type [1]. The starting point of the composite aluminium-silicon coagulant is to utilise the highly polymerised silica to improve the aggregation efficiency of the aluminium salts. In general, there are two approaches used to prepare composite aluminium-silicon coagulants. One approach consists of introducing aluminium salts into polysilicic acid (PSA) to produce an aluminium-polysilicate coagulant [2], which is more stable than the conventional coagulation aid, the activated silica. The aluminium-polysilicate offers better performance than ordinary aluminium salts in the coagulation processes, but it has limited storage life and low effective concentration of aluminium, thus limiting its commercial production. The second approach originates from a patent technology for the production of polyaluminium silicate sulphate (PASS) coagulant [3], for which three conventional chemicals, namely aluminium sulphate, sodium aluminate and sodium silicate are used as raw materials. PASS is produced and used in Canada and the UK, and has demonstrated good coagulation properties. However, the production process is complicated and the cost of production is still high. It remains a possible and suitable approach when abundant and cheap raw materials are available. In China, Japan, and elsewhere, polyaluminium chloride (PAC) is becoming popular as an efficient inorganic polymer coagulant. For instance, many modern PAC factories have been built in China, and the total annual production has now reached 500,000 metric tons. If more efficient, composite aluminium-silicon coagulants based on PAC can be developed, the economical production is feasible.

For this paper, a composite aluminium-silicon coagulant, the polyaluminium silicate chloride (PASC) was prepared by using aluminium chloride, sodium hydroxide, sodium silicate, and hydrochloric acid. The aluminium speciation, particle size distribution, electrokinetic and coagulation properties of PASC were studied using aluminium-27 nuclear magnetic resonance $\left({ }^{27} \mathrm{Al}\right.$ NMR) spectroscopy, photon correlation spectroscopy (PCS), 
streaming current (SC) measurement, jar tests and pilot-scale water treatment tests. These studies are very important for understanding the characteristics of PASC and could lay the foundation for its economical production.

\section{MATERIALS AND METHODS}

All chemicals used were of analytical grade, and solutions were prepared with deionised water. The standard stock solution of 1.0 mole per litre $\left(\mathrm{mol} \mathrm{l}^{-1}\right) \mathrm{NaOH}$ was prepared with deionised $\mathrm{CO}_{2}$-free water.

\section{Preparation of PASC}

A series of $0.20 \mathrm{~mol} \mathrm{l}^{-1}$ PAC solutions with hydroxyl to aluminium molar ratios $(\mathrm{OH} / \mathrm{Al})$ of $0.50,1.0$, and 2.0 were prepared by the titration of $0.40 \mathrm{~mol} \mathrm{l}^{-1} \mathrm{AlCl}_{3}$ with $1.0 \mathrm{~mol} \mathrm{l}^{-1}$ $\mathrm{NaOH}$ under magnetic stirring. The addition of $\mathrm{NaOH}$ was controlled at $0.80 \mathrm{ml}$ per minute. After the titration was completed, the PAC solutions were kept in a water bath at $75^{\circ} \mathrm{C}$ until clear solutions were obtained. PSA solution $(0.15$ $\mathrm{mol}^{-1}$ as $\mathrm{Si}$ ) with $\mathrm{pH} 1.8$ was prepared by the fast titration of $0.30 \mathrm{~mol} \mathrm{l}^{-1} \mathrm{Na}_{2} \mathrm{SiO}_{3}$ with $3.0 \mathrm{~mol} \mathrm{I}^{-1}$ hydrochloric acid. This PSA was allowed to polymerise in a water bath at $30^{\circ} \mathrm{C}$ for 60 minutes (min). A series of $0.10 \mathrm{~mol} \mathrm{I}^{-1}$ PASC samples with silicon to aluminium molar ratios (Si/Al) of $0.025,0.050$, and 0.075 were prepared by mixing the PAC and PSA solutions. AII PASC and PAC samples remained clear and stable for at least two months at $20^{\circ} \mathrm{C}$.

Aluminium Speciation and Particle Size Distribution Measurements

Aluminium speciation of PASC and PAC was studied using ${ }^{27} \mathrm{Al}$ NMR spectroscopic measurements with FX-90Q NMR Spectrometer (JEOL Ltd., Japan). Sodium aluminate solution $\left(0.1 \mathrm{~mol} \mathrm{l}^{-1}\right)$ as internal standard and the same volume of deuterated water as block were filled in capillary tubes of $0.226 \mathrm{~mm}$ diameter and $0.018 \mathrm{~mm}$ wall thickness. These tubes were inserted into the sample tubes of $10 \mathrm{~mm}$ diameter and $0.50 \mathrm{~mm}$ wall thickness. The measurements were performed under a frequency of $23.31 \mathrm{MHz}$ at $20^{\circ} \mathrm{C}$. Particle size distribution in PASC and PAC solutions was studied using photon correlation spectroscopic measurements with BI200SM Laser Light Scattering Instrument (Brookhaven Instruments Corp., USA). The sample $\left(0.10 \mathrm{~mol} \mathrm{l}^{-1}\right)$ was directly introduced into a quartz cell and PCS spectra were obtained at $20{ }^{\circ} \mathrm{C}$. The non-negatively constrained leastsquares method (NNLS) was used for data processing, and the particle size distribution was expressed in terms of volume percent with respect to particle diameter.

\section{Streaming Current Measurement}

The electrokinetic properties of PASC were studied by measuring the SC value of the coagulant hydrolysate using
SC-30S Streaming Current Detector (SCD) (Beijing Precise Single-Factor Co. Ltd., China). Water for SC measurements was prepared by mixing deionised water with tap water, which had a conductivity of $200 \mathrm{mS} \mathrm{cm}^{-1}$ at $20^{\circ} \mathrm{C}$. PASC or PAC sample was slowly added to $2000 \mathrm{ml}$ of the above water in a beaker with continuous stirring. The $\mathrm{pH}$ of the water was kept at 7.0 by the addition of $1.0 \mathrm{~mol} \mathrm{I}^{-1} \mathrm{NaOH}$ and the streaming current of the water was measured.

\section{Coagulation Tests}

The coagulation properties of PASC were first studied using jar tests with synthetic turbid water on a WT-6P Jar Tester (Sugiyamagen Co. Ltd., Japan), and the turbidity was measured by a Lamotte 2008 Turbidimeter (Lamotte Co. Ltd, USA). The synthetic turbid water was prepared by mixing deionised water and tap water $[1: 1(\mathrm{v} / \mathrm{v})]$ and adding $100 \mathrm{mg}$ $1^{-1}$ kaolinite. The mixture had a turbidity of 70.0 Nephelometric Turbịdity Units (NTU) and a pH of 7.75. PASC or PAC was added to $500 \mathrm{ml}$ of synthetic water sample while continuously stirring at $180 \mathrm{rpm}$. After the addition, this mixture was first stirred at $180 \mathrm{rpm}$ for $1 \mathrm{~min}$, then at $40 \mathrm{rpm}$ for $10 \mathrm{~min}$, and finally was kept undisturbed for $10 \mathrm{~min}$. The residual turbidity was measured with a sample taken at $2 \mathrm{~cm}$ below the water level.

The performance of the PASC coagulant for real water treatment was investigated in a pilot plant built in the Ninth Water Treatment Plant at Beijing. The raw water came from the Miyun Reservoir, the largest water resource for the city of Beijing. The water had a low turbidity of 1.2-1.9 NTU, a temperature of $5.8-6.0^{\circ} \mathrm{C}$, and a $\mathrm{pH}$ value of around 7.5. In the coagulation sedimentation process, raw water at a flow rate of $1.5 \mathrm{~m}^{3} \mathrm{~h}^{-1}$ was automatically dosed with $0.1 \mathrm{~mol} \mathrm{l^{-1 }}$ coagulant and mixed mechanically in a mixing tank under a stirring velocity gradient of $613 \mathrm{~s}^{-1}$ for $1 \mathrm{~min}$. Then the water entered a flocculation reactor and was flocculated under a stirring velocity gradient of $80 \mathrm{~s}^{-1}$ for $10 \mathrm{~min}$ before being finally clarified in a settling tank for $40 \mathrm{~min}$. The turbidity of the influent and the effluent was measured on-line. The effluent turbidity would reach a stable value in $2.5 \mathrm{~h}$ after a dosage was set, and this value was taken as the index of the treated water quality.

\section{RESULTS AND DISCUSSION}

Preparation Conditions and Compositions of PASC

One difficulty in the preparation of PASC can come from the positively charged acidic compound PAC. However, the conventional .PSA, i.e., the "Balis" solution for water treatment has a $\mathrm{pH}$ of 8.5 and is negatively charged [4]. When they are mixed, both acid-base neutralisation and charge neutralisation take place, resulting in gelation or precipitation so that a stable and homogeneous sample cannot be obtained It is reasonable to prepare a positively or zero charged PSA for the preparation of PASC. The isoelectric point of the 
polysilicic acid was reported to be between $\mathrm{pH} 1.5$ and 2 [5]. In the present study, the sodium silicate was acidified to $\mathrm{pH}$ 1.8 and then allowed to polymerise to PSA. The optimum polymerisation time of PSA was $60 \mathrm{~min}$ at a concentration of $0.15 \mathrm{~mol} \mathrm{l}^{-1}$. It was also found that aluminium concentrations lower than $0.20 \mathrm{~mol} \mathrm{l}^{-1}$ and $\mathrm{Si} / \mathrm{Al}$ ratios lower than 0.10 should be maintained to prepare stable and homogeneous PASC samples; otherwise, gelation or precipitation would occur in several minutes to several hours.

The compositions and $\mathrm{pH}$ values of PASC and PAC samples are listed in Table 1. The $\mathrm{OH} / \mathrm{Al}$ ratio is an important

Table 1. The compositions and $\mathrm{pH}$ values of PASC and PAC (Aluminium concentration, $0.10 \mathrm{~mol}^{-1}$ ).

\begin{tabular}{lccc}
\hline & \multicolumn{3}{c}{$\mathrm{pH}$ value } \\
\cline { 2 - 4 } $\mathrm{Si} / \mathrm{Al}$ & $\mathrm{OH} / \mathrm{Al}: 2.0$ & $\mathrm{OH} / \mathrm{Al}: 1.0$ & $\mathrm{OH} / \mathrm{Al}: 0.50$ \\
\hline 0 & 3.93 & 3.88 & 3.65 \\
0.025 & 3.90 & 3.84 & 3.63 \\
0.050 & 3.88 & 3.81 & 3.60 \\
0.075 & 3.85 & 3.79 & 3.58 \\
\hline
\end{tabular}

parameter of the polymeric coagulant to indicate the polymeric extent of aluminium. Since the quantity of PSA in PASC was so limited ( $\mathrm{Si} / \mathrm{Al}<0.10$ ), we can approximately take the $\mathrm{OH} / \mathrm{Al}$ ratio of $\mathrm{PAC}$ as one of the parameters of
PASC to indicate the polymeric extent of aluminium. The relative content of silicon in $\mathrm{PASC}$, i.e., $\mathrm{Si} / \mathrm{Al}$ ratio, is another important parameter of the composite coagulant.

\section{Aluminium Speciation and Particle Size Distribution of PASC}

Figure 1 shows the ${ }^{27} \mathrm{AI}$ NMR spectra of PASC and PAC with an $\mathrm{OH} / \mathrm{Al}$ ratio of 2.0. Three sets of resonance peaks with chemical shifts $0.0,62.5$, and 79.8 parts per million (ppm) appeared in the spectra. The three sets of resonance peaks could be attributed to monomeric aluminium $\left(\mathrm{Al}_{\mathrm{m}}\right)$, polynuclear aluminium $\left[\mathrm{AlO}_{4} \mathrm{Al}_{12}(\mathrm{OH})_{24}\left(\mathrm{H}_{2} \mathrm{O}\right)_{12}\right]^{7+}\left(\mathrm{Al}_{13}\right)$, and the internal standard $\mathrm{Al}(\mathrm{OH})_{4}$, , respectively [6-8]. According to the areas of the resonance peaks, the percent of different aluminium species $\mathrm{Al}_{\mathrm{m},} \mathrm{Al}_{13}$, and other aluminium species not appearing in the spectra $\left(\mathrm{Al}_{\text {oth }}\right)$ can be calculated [9]. The effects of $\mathrm{OH} / \mathrm{Al}$ and $\mathrm{Si} / \mathrm{Al}$ ratios on the aluminium speciation of PASC are shown in Figure 2. Both $\mathrm{OH} / \mathrm{Al}$ and $\mathrm{Si} / \mathrm{Al}$ ratios affect the aluminium speciation of $\mathrm{PASC}$, but the effect of the former is much greater than that of the latter. With an increase in the $\mathrm{OH} / \mathrm{Al}$ ratio, $\mathrm{Al}_{\mathrm{m}}$ gradually decreased, while $\mathrm{Al}_{13}$ and $\mathrm{Al}_{\text {oth }}$ increased. With an increase in the $\mathrm{Si} / \mathrm{Al}$ ratio, $\mathrm{Al}_{\mathrm{m}}$ and $\mathrm{Al}_{\text {oth }}$ increased, but $\mathrm{Al}_{13}$ decreased. The effect of the $\mathrm{Si} / \mathrm{Al}$ ratio on the aluminium speciation probably resulted from the higher acidity of PASC compared to that of PAC. Under certain $\mathrm{OH} / \mathrm{Al}$ ratios (Table 1), the $\mathrm{pH}$ of PASC was lower than that $\mathrm{PAC}$ and decreased with an increase in the $\mathrm{Si} / \mathrm{Al}$ ratio. The lower $\mathrm{pH}$ might cause the conversion of the polynuclear aluminium species $\left(\mathrm{Al}_{13}\right)$ into

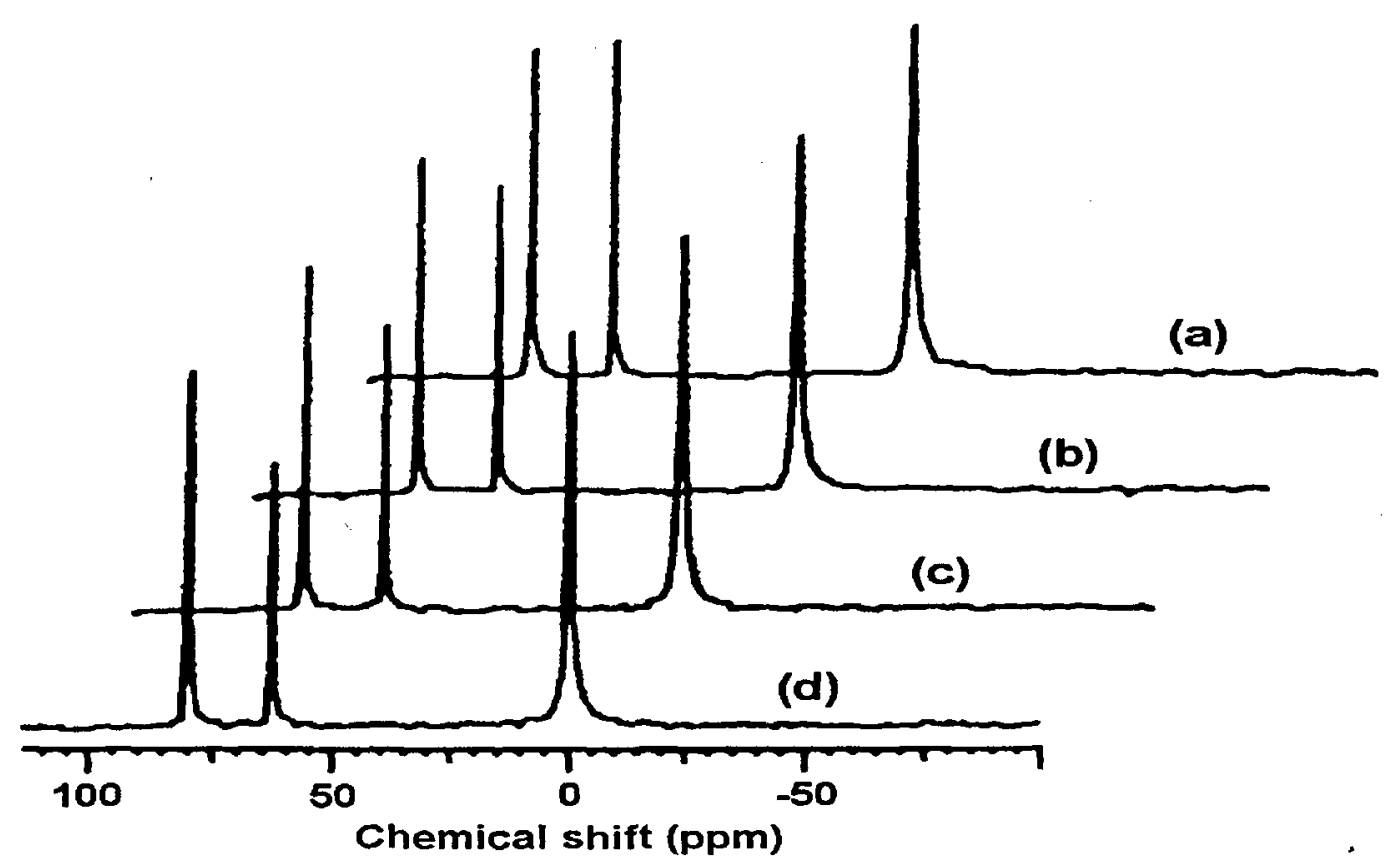

Figure 1. The ${ }^{27} \mathrm{Al} \mathrm{NMR} \mathrm{spectra} \mathrm{of} \mathrm{PASC} \mathrm{and} \mathrm{PAC}$ with a OH$/ \mathrm{Al}$ of 2.0. (a) $\mathrm{PAC}$, (b) $\mathrm{Si} / \mathrm{Al}=0.025$, (c) $\mathrm{Si} / \mathrm{Al}=0.050,(\mathrm{~d}) \mathrm{Si} / \mathrm{Al}=$ 0.075 . 

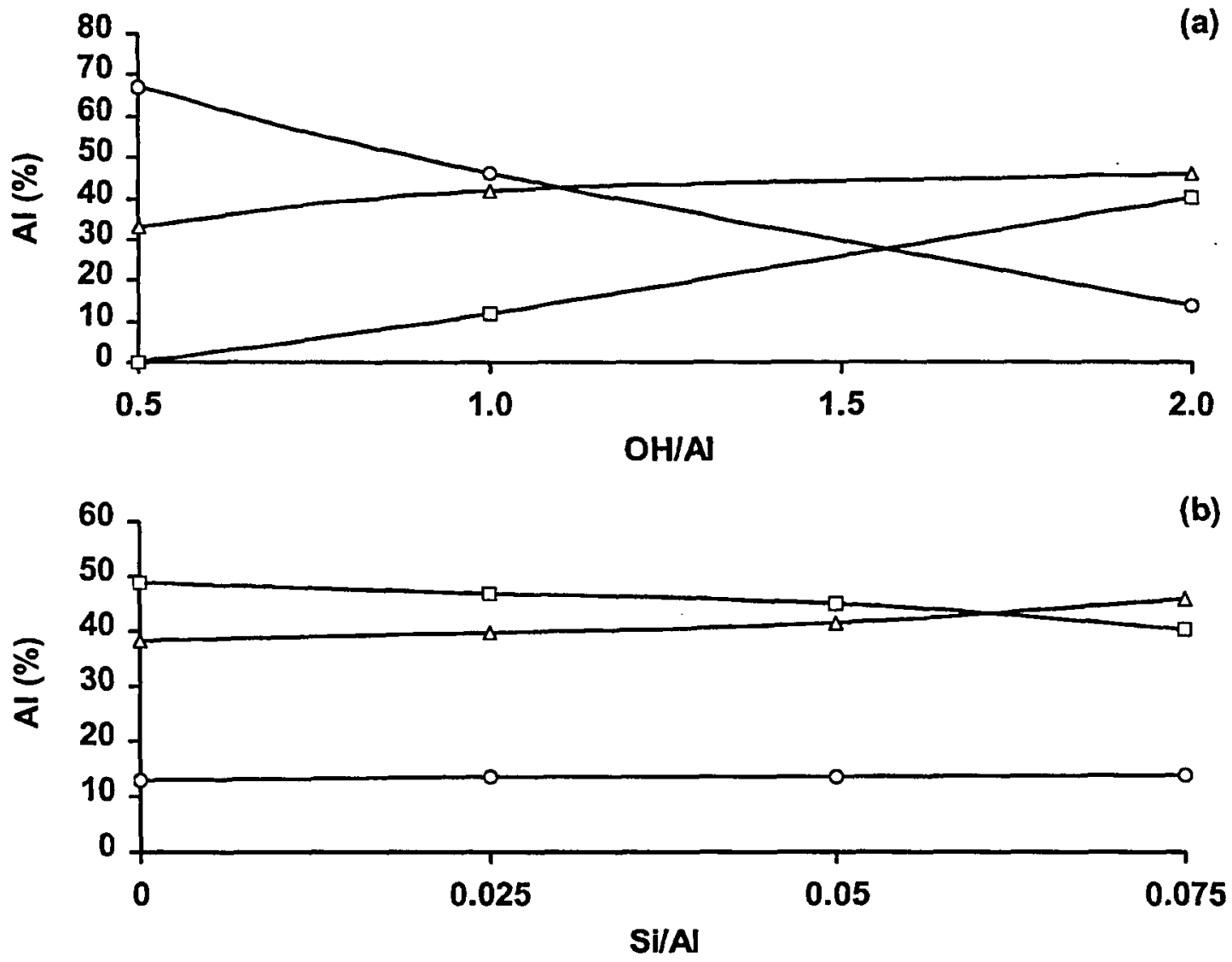

Figure 2. (a) The effect of $\mathrm{OH} / \mathrm{Al}$ ratio on the aluminium speciation of $\mathrm{PASC}$ at a Si / $\mathrm{Al}$ of 0.075 , and (b) the effect of $\mathrm{Si} / \mathrm{Al}$ ratio on the aluminium speciation of PASC at a OH/Al of 2.0. O: $\mathrm{Al}_{\mathrm{m}} \%, \square: \mathrm{Al}_{13} \%, \Delta: \mathrm{Al}_{\mathrm{oth}} \%$.

monomeric species. That could explain why the monomeric species increased slightly with an increase in the $\mathrm{Si} / \mathrm{Al}$ ratio. It might be possible that the increase in the $\mathrm{Si} / \mathrm{Al}$ ratio also caused the formation of new species containing $\mathrm{Al}$ and $\mathrm{Si}$ that were not detected by NMR. According to Parthasarathy and Buffle [10], $\mathrm{Al}_{13}$ is highly positively charged and represents an effective component of the polymeric aluminium coagulants. It is reasonable to aim at obtaining high $\mathrm{Al}_{13}$ content in the production of polymeric aluminium coagulants. Considering the two parameters of PASC, the increase of the $\mathrm{OH} / \mathrm{Al}$ ratio could greatly increase the content of $\mathrm{Al}_{13}$, which could improve the coagulation efficiency of PASC. On the other hand, the increase of the $\mathrm{Si} / \mathrm{Al}$ ratio could slightly decrease the amount of $\mathrm{Al}_{13}$, and this might have a negative effect on the coagulation efficiency of PASC.

The particle size distribution of a coagulant has a great influence on its coagulation efficiency. Figure 3 shows the PCS spectra of PASC and PAC with an $\mathrm{OH} / \mathrm{AI}$ ratio of 2.0. The particle size of the PASC with a $\mathrm{Si} / \mathrm{Al}$ ratio of 0.075 ranged from 13 to $1900 \mathrm{~nm}$, and the particles larger than $50 \mathrm{~nm}$ represented more than $20 \%$ of the total. The particle size of the PASC with a Si/Al ratio of 0.050 ranged from 4 to $50 \mathrm{~nm}$, but the particles smaller than $10 \mathrm{~nm}$ accounted for more than $90 \%$ of the total. The particle size distributions of the PASC with a
$\mathrm{Si} / \mathrm{Al}$ ratio of 0.025 were similar to that of PAC and all the particles were smaller than $2 \mathrm{~nm}$. The above PCS measurements showed that the $\mathrm{Si} / \mathrm{Al}$ ratio had a distinct effect on the particle size distribution of PASC. With an increase in the $\mathrm{Si} / \mathrm{Al}$ ratio, the proportions of the large particles gradually increased, indicating that in the coagulation process PASC might have much stronger adsorption-bridging ability than PAC.

The Electrokinetic Properties of PASC

SCD is an electrokinetic analyser for characterising charge properties of particles in aqueous suspension. Knosche et al. [11] found an excellent agreement between the results of microelectrophoresis and streaming current measurements of the suspensions. AbuOrf and Dental [12] reported that SCD was suitable for monitoring polymer dosage. For this paper, SCD was employed to investigate the electrokinetic properties of PASC since a direct measurement of the hydrolytic coagulant by electrophoresis proved to be fairly difficult. Figure 4 shows the effects of $\mathrm{OH} / \mathrm{Al}$ and $\mathrm{Si} / \mathrm{Al}$ ratios on the $\mathrm{SC}$ of PASC at $\mathrm{pH}$ 7.0. Figure 4a shows that with an increase in PASC dosage, the SC gradually increased from a negative to a positive value. With an increase in the $\mathrm{OH} / \mathrm{Al}$ ratio, the 


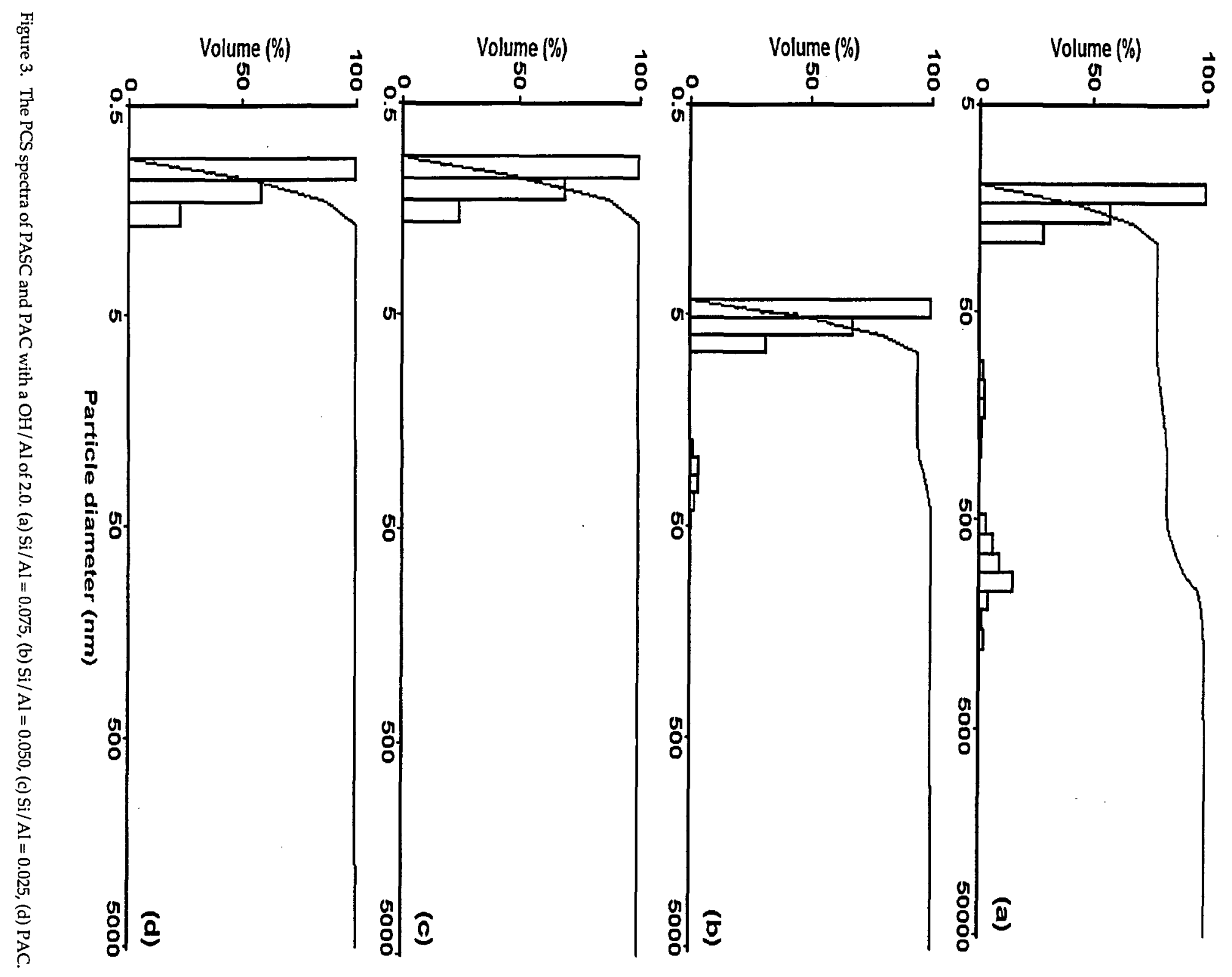



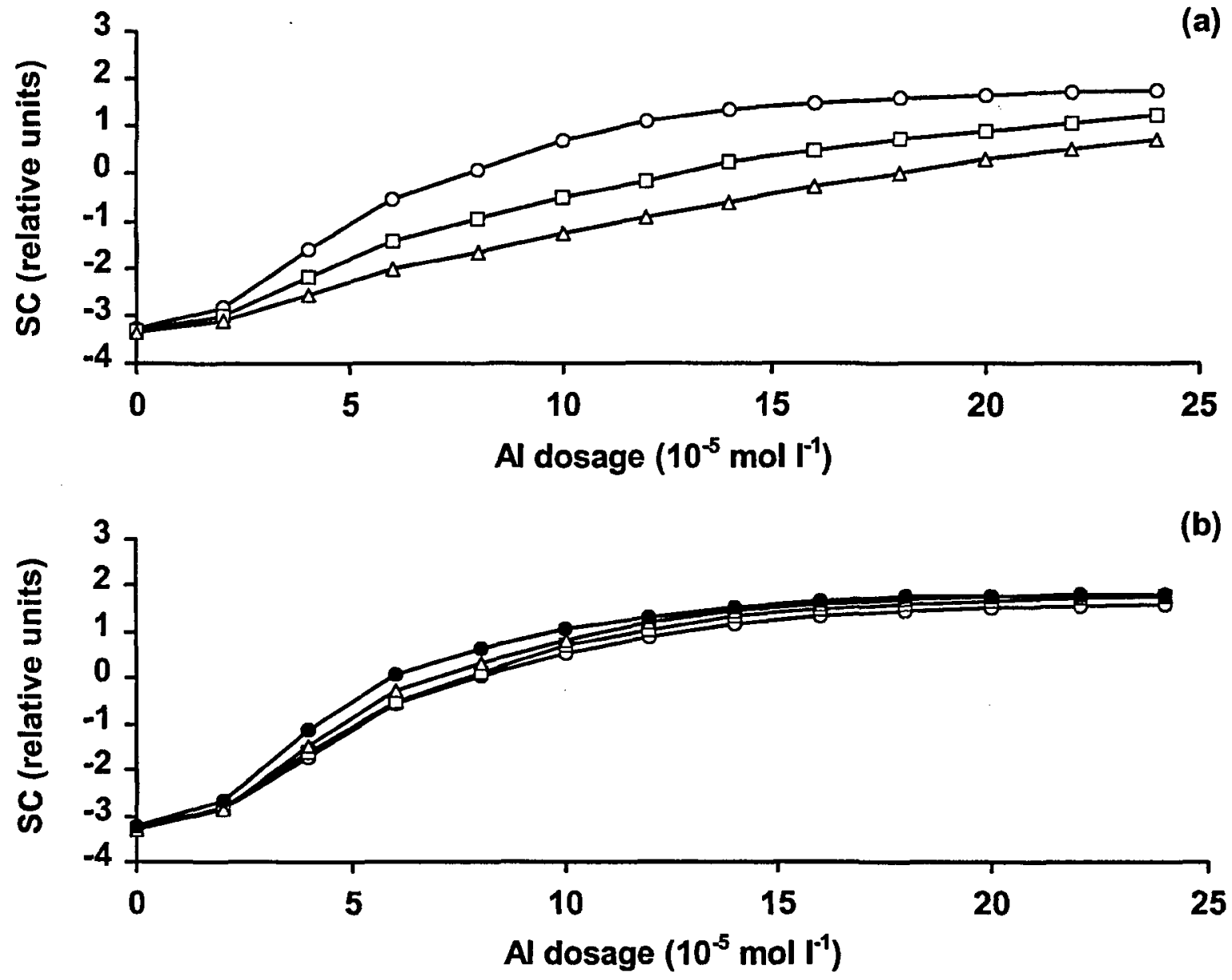

Figure 4. (a) The effect of $\mathrm{OH} / \mathrm{Al}$ ratio on the SC of PASC at a Si $/ \mathrm{Al}$ of $0.050(\mathrm{O}: \mathrm{OH} / \mathrm{Al}=2.0, \square: \mathrm{OH} / \mathrm{Al}=1.0, \Delta: \mathrm{OH} / \mathrm{Al}$ $=0.50$ ), and (b) the effect of $\mathrm{Si} / \mathrm{Al}$ ratio on the SC of PASC at a OH/Al of $2.0(\mathrm{O}: \mathrm{Si} / \mathrm{Al}=0.075, \square: \mathrm{Si} / \mathrm{Al}=0.050$, $\Delta: \mathrm{Si} / \mathrm{Al}=0.025, \mathrm{O}: \mathrm{PAC}$ ).

dosages to arrive at zero-SC decreased. The zero-SC dosages for $\mathrm{PASC}$ with a $\mathrm{Si} / \mathrm{Al}$ ratio of 0.050 and $\mathrm{OH} / \mathrm{Al}$ ratios of 0.50 , 1.0 , and 2.0 were $1.8 \times 10^{-4}, 1.25 \times 10^{-4}$, and $7.5 \times 10^{-5} \mathrm{~mol} \mathrm{l}^{-1}$, respectively. This means that the PASC with higher $\mathrm{OH} / \mathrm{Al}$ ratios had higher charge neutralisation capacities. Figure $4 \mathrm{~b}$ shows that the SC of PASC was lower than that of PAC. With an increase in the $\mathrm{Si} / \mathrm{Al}$ ratio, the $\mathrm{SC}$ value decreased, but compared to the $\mathrm{OH} / \mathrm{Al}$ ratio, the effect of the $\mathrm{Si} / \mathrm{Al}$ ratio on the SC of PASC was much smaller.

The effects of $\mathrm{OH} / \mathrm{AI}$ and $\mathrm{Si} / \mathrm{Al}$ ratios on the $\mathrm{SC}$ of PASC can be attributed to the speciation characteristics of PASC. The polynuclear aluminium $\mathrm{Al}_{13}$ is highly positively charged and the content of $\mathrm{Al}_{13}$ in a polymeric aluminium coagulant is the dominant factor controlling its charge neutralisation capacity. With an increase in the $\mathrm{OH} / \mathrm{Al}$ ratio, the content of $\mathrm{Al}_{13}$ in PASC increased, so the charge neutralisation capacity of PASC also improved in water. The polysilicic component in PASC caused a decrease in the content of the $\mathrm{Al}_{13}$ species, thus reducing its positive charge.
Consequently PASC had a lower SC value than PAC and the tendency intensified with the increase in the $\mathrm{Si} / \mathrm{Al}$ ratio. By comparing the effects of $\mathrm{OH} / \mathrm{Al}$ and $\mathrm{Si} / \mathrm{Al}$ ratios on the electrokinetic properties of PASC, we saw that the $\mathrm{OH} / \mathrm{Al}$ ratio of PASC was still the most important parameter, and that an increase in this ratio benefited the charge neutralisation capacity of the composite coagulant. The increase of the $\mathrm{Si} / \mathrm{Al}$ ratio slightly weakened the charge neutralisation capacity of PASC, which might in turn affect its coagulation efficiency.

\section{The Coagulation Properties of PASC}

The results of jar tests showed that an increase in the $\mathrm{OH} / \mathrm{Al}$ ratio improved the coagulation efficiency of PASC in turbid water treatment and this was similar to that of PAC [13]. The PASC with a higher $\mathrm{OH} / \mathrm{Al}$ ratio contained more polynuclear aluminium $\mathrm{Al}_{13}$, had higher charge neutralisation capacity, and had better coagulation properties. Since PASC is 
a composite silicon-containing coagulant, the effect of the $\mathrm{Si} / \mathrm{Al}$ ratio on the coagulation properties should be noticeable. Figure 5a shows that PASC was more efficient than PAC in turbidity removal, and an increase in the $\mathrm{Si} / \mathrm{Al}$ ratio improved the coagulation efficiencies. Figure $5 b$ compares the effectiveness for turbidity removal between PASC and PAC in the $\mathrm{pH}$ range from 4.0 to 10.0 , and PASC showed better coagulation efficiencies than PAC. PASC was much more
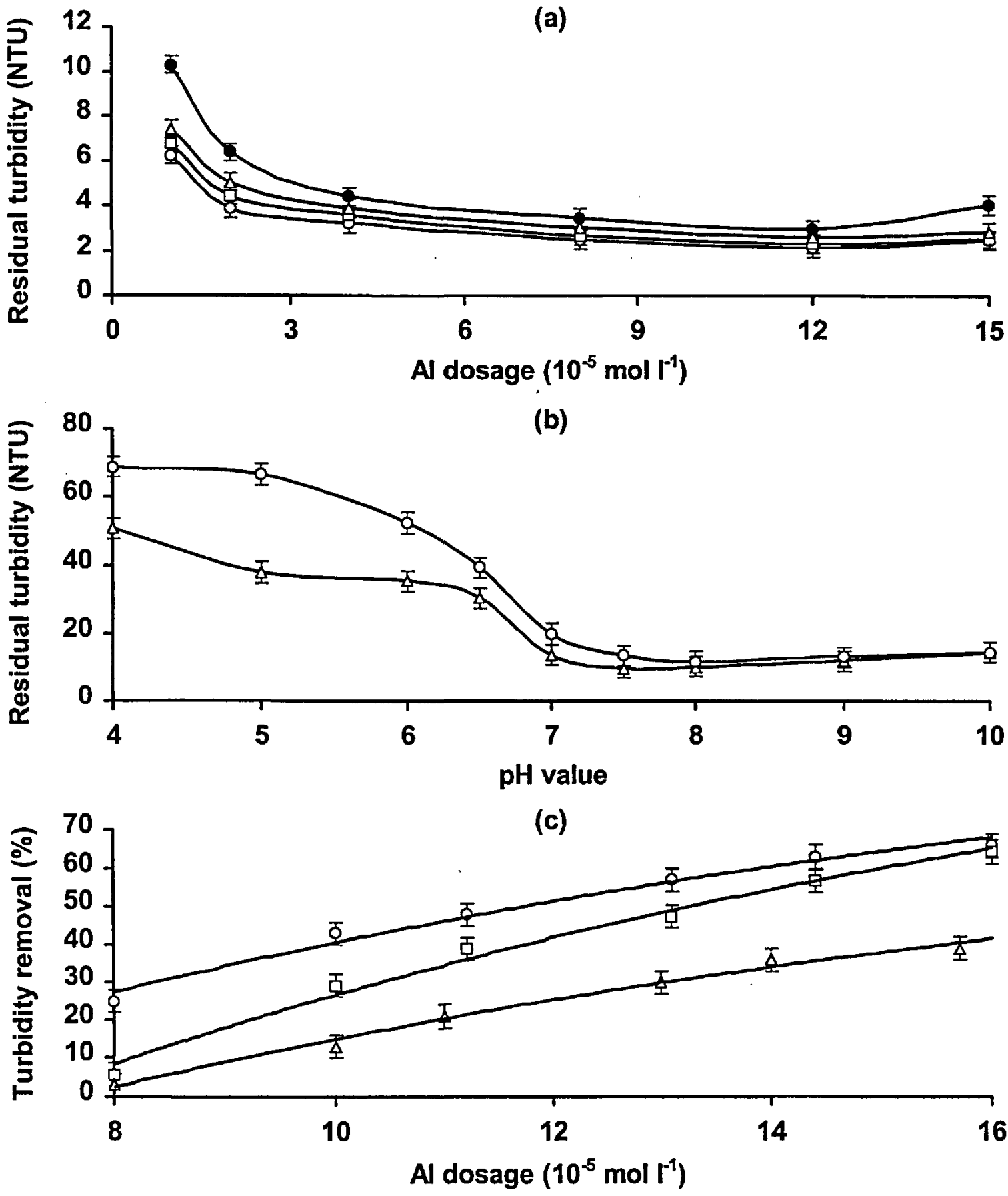

Figure 5. (a) The effect of Si/Al ratio on the coagulation properties of PASC (PASC and PAC have a OH/Al of 2.0; O: $\mathrm{Si} / \mathrm{Al}=0.075, \square: \mathrm{Si} / \mathrm{Al}=0.050, \Delta: \mathrm{Si} / \mathrm{Al}=0.025, \bullet: \mathrm{PAC}$ ).

(b) the comparison of the coagulation efficiencies between PASC and PAC at a OH/ $\mathrm{Al}$ of 2.0 and an $\mathrm{Al}$ dosage of $2.0 \times 10^{-5} \mathrm{~mol} \mathrm{l}^{-1}$ ( $\triangle$ : PASC, O PAC).

(c) the efficiencies of PASC, PAC and AS for low turbidity and low temperature-water treatment (O: PASC, $\mathrm{Si} / \mathrm{Al}=0.075 ; \square$ : PAC, $\Delta: \mathrm{AS}$ ). 
efficient than PAC below $\mathrm{pH}$ 8.0, especially below $\mathrm{pH} 6.5$, but above $\mathrm{pH} 8.0$ the efficiencies of PASC and PAC were closer. To illustrate the effect of the Si/Al ratio on the coagulation properties of PASC, comprehensive considerations are needed. The studies of aluminium speciation showed that PASC had less polynuclear aluminium $\mathrm{Al}_{13}$ than $\mathrm{PAC}$ and the $\mathrm{Al}_{13}$ in PASC decreased with an increase in Si/Al. Electrokinetic studies showed that PASC had a slightly weaker charge neutralisation capacity than PAC, and the charge neutralisation capacity of PASC decreased with an increase in the $\mathrm{Si} / \mathrm{Al}$ ratio. These factors had a negative influence on the coagulation efficiency of PASC. However, the polysilicic component in PASC had a great influence on the particle size of this composite coagulant, and the higher $\mathrm{Si} / \mathrm{Al}$ ratio the PASC had, the larger particles it contained. These larger particles had a more powerful adsorption-bridging ability than the smaller ones, so the polysilicic component had a great positive influence on the coagulation efficiency of PASC. The main motivation for the development of a new composite coagulant is the net enhancement of its coagulation efficiency for water treatment. When polysilicic acid was combined with PAC to produce PASC, the most effective aluminium species and the charge neutralisation capacity were slightly weakened, but the particle size of the composite coagulant greatly enlarged. However, a net enhancement of coagulation efficiency was obtained. From the point of view of getting a high efficiency and stable composite coagulant, a PASC with $\mathrm{Si} / \mathrm{Al}$ ratio higher than 0.10 is hard to obtain, so the negative effect of the high $\mathrm{Si} / \mathrm{Al}$ ratio outstripping the positive effect is not a worry. Obviously PASC was much more efficient than PAC under acidic conditions. This also reinforced the importance of large particle size. Under acidic conditions, the hydrolysis of aluminium was more or less retarded and the polysilicic component in PASC played an important role of adsorption-bridging. However, in the basic $\mathrm{pH}$ range, the hydrolysis of aluminium was faster; the hydrolysed and polymerised aluminium species also played important roles of adsorption-bridging, and the role of the polysilicic component was not as obvious as in the acidic $\mathrm{pH}$ range.

The results of the pilot tests for low turbidity and low temperature-water treatment are illustrated in Figure $5 c$. They show that PASC was more efficient than the conventional coagulants, aluminium sulphate (AS) and PAC. The turbidity removal efficiency of PASC with an $\mathrm{OH} / \mathrm{Al}$ ratio of 2.0 and a $\mathrm{Si} / \mathrm{Al}$ ratio of 0.075 was generally $10 \%$ higher than that of the corresponding PAC and $25 \%$ higher than that of AS. It is well known that the treatment of low turbidity and low temperature-water is rather difficult, but PASC coagulant performed well in the pilot tests.

Perspectives on the Production of PASC Coagulant

The results show that PASC is a promising coagulant for water treatment. First, it is a cost-effective coagulant. In comparison with the production of PAC, the main additional material for the production of PASC is sodium silicate, which can come from inexpensive industrial water glass. Considering the low silicon content in the PASC coagulant ( $\mathrm{Si} / \mathrm{Al}<0.10$ ), the material cost for the production of PASC will be only slightly higher than for PAC. With the techniques for PSA preparation and control on the $\mathrm{Si} / \mathrm{Al}$ ratio presented in this paper, the production of PASC using commercial PAC and industrial water glass is feasible. Secondly, PASC is a healthy coagulant. Because of the universal presence of the soluble silica in natural water, it is considered harmless in drinking water [14], and the activated silica solutions have long been used as a coagulation aid in water treatment [4]. The existence of the polysilicic component in PASC can hopefully decrease the residual aluminium in treated water since it has been shown that the utilisation of the PASS coagulant in water treatment may lead to low aluminium residuals [15]. The advantages of PASC coagulant should be investigated in large-scale water treatment practice, and this is under progress.

\section{CONCLUSIONS}

A composite aluminium-silicon coagulant, PASC, was prepared by mixing aluminium chloride, sodium hydroxide, sodium silicate, and hydrochloric acid. The preparation process was compounding preparations of PAC and PSA. $\mathrm{PASC}$ had an $\mathrm{OH} / \mathrm{Al}$ ratio ranging from 0.5 to 2.0 with $\mathrm{Si} / \mathrm{Al}$ ratios below 0.10 . The characterisation of PASC showed that it had a little less $\mathrm{Al}_{13}$ and smaller charge neutralisation capacity than PAC. However, the particles composing the PASC were much larger than those of $\mathrm{PAC}$, especially at $\mathrm{Si} / \mathrm{Al}$ ratios above 0.050, giving PASC higher coagulation efficiency for water treatment than PAC. An increase in the Si/ $\mathrm{Al}$ and/or $\mathrm{OH} / \mathrm{AI}$ ratios increased the coagulation efficiency of PASC. In a wide $\mathrm{pH}$ range of 4.0-10.0, PASC showed better performance than PAC, especially at $\mathrm{pH}$ values below 8.0. Coagulation tests showed that PASC had better performance in low turbidity and low temperature-water treatment than both AS and PAC. The results show that PASC is an efficient and promising composite coagulant for water treatment, and the commercial production of PASC is practical and feasible.

\section{ACKNOWLEDGEMENTS}

The study was part of the State Key Project of $9^{\text {th }}$ Fiveyear Plan of China, Coordinate High Technology for Effective Flocculants, Efficient Reactor and Beneficial Auto-dosing. We thank Prof. B.Y. Gao of Shandong University and Dr. J.H. Gu of the authors' laboratory for their technical assistance, and Prof. N. Belzile of Laurentian University of Canada, Prof. C. Namasivayam of Bharathiar University of India, and Mr. D. Etheridge of United Arab Emirates University for their help with the revision of the paper. 
1. Tang H.X., Luan Z.K., Wang D.S. and Gao B.Y., Composite inorganic polymer flocculants. In: Chemical Water and Wastewater Treatment, V, Hahn H.H., Hoffmann E. and Ødegaard H. (Eds.), Springer-Verlag, Berlin, Germany, pp. 25-34 (1998).

2. Hasegawa T., Hashimoto K., Onitsuka T., Goto K. and Tambo N., Characteristics of metal-polysilicate coagulants. Water Sci. Technol., 23, 1713-1722 (1991).

3. Hasse D., Spiratos N. and Jolicoeur C. (Handy Chemicals Ltd.), Polymeric basic aluminum silicate-sulphate. US patent 4981675 (1991).

4. Iler R.K., The Chemistry of Silica, John Wiley \& Sons, New York, USA, pp. 301-303 (1979).

5. Iler R.K., The Chemistry of Silica, John Wiley \& Sons, New York, USA, pp. 186-189 (1979).

6. Bertsch P.M., Thomas G.W. and Barnhisel R.I., Characterization of hydroxy-aluminum solutions by aluminum-27 nuclear magnetic resonance spectroscopy. Soil Sci. Soc. Am. J., 50, 825-830 (1986).

7. Bertsch P.M., Layton W.J. and Barnhisel R.I., Speciation of hydroxy-aluminum solutions by wet chemical and aluminum-27 NMR methods. Soil Sci. Soc. Am. I., 50, 1449-1454 (1986).

8. Bertsch P.M., Anderson M.A. and Layton W.J., Aluminum-27 nuclear magnetic resonance studies of ferron-hydroxopolynuclear aluminum interactions. Magn. Reson. Chem., 27, 283-287 (1989).

9. Gao B, Li C. and Yu H., Study on speciation of Al in PSAA solution. Zhongguo Huanjing Kexue, 17, $279-282$ (1997).

10. Parthasarathy N. and Buffle J., Study of polymeric aluminum (III) hydroxide solutions for application in water and waste water treatment. Properties of the polymer and optimal conditions of preparation. Water Res., 19, 25-36 (1985).

11. Knosche C., Friedrich H. and Stintz M., Determination of particle size distributions and electrokinetic properties with the AcoustoSizer in comparison with other methods. Part. \& Part. Syst. Charact., 14, 175-180 (1997).

12. AbuOrf M.M. and Dental S.K., Polymer dose assessment using the streaming current detector. Water Environ. Res., 69, 10751085 (1997).

13. Tang H.X. and Luan Z.K., Features and mechanism for coagulation-flocculation processes of polyaluminum chloride. $J$. Environ. Sci. (China), 7, 204-211 (1995).

14. Iler R.K., The Chemistry of Silica, John Wiley \& Sons, New York, USA, pp. 757-758 (1979).

15. Arnold-Smith A.K., Christie R.M. and Jolicoeur C., Polyaluminum silicate sulphate-a new coagulant for potable and wastewater treatment. In: Chemical Water and Wastewater Treatment, II, Klute R. and Hahn H.H. (Eds.), Springer-Verlag, Berlin, Germany, pp. 203-219 (1992). 